\title{
LUPUS SCIENCE\& MEDICINE \\ Efficacy and safety of rituximab biosimilar in refractory lupus
}

\author{
Nantakarn Pongtarakulpanit, Prapaporn Pisitkun, Pintip Ngamjanyaporn
}

To cite: Pongtarakulpanit N, Pisitkun P, Ngamjanyaporn P. Efficacy and safety of rituximab biosimilar in refractory lupus. Lupus Science \& Medicine 2020;7:e000442. doi:10.1136/ lupus-2020-000442

Received 28 August 2020 Revised 14 0ctober 2020 Accepted 21 October 2020

\section{Check for updates}

(c) Author(s) (or their employer(s)) 2020. Re-use permitted under CC BY-NC. No commercial re-use. See rights and permissions. Published by BMJ.

Division of Allergy, Immunology and Rheumatology, Department of Medicine, Faculty of Medicine Ramathibodi Hospital, Mahidol University, Bangkok, Thailand

Correspondence to

Dr Pintip Ngamjanyaporn; pintip. nga@mahidol.ac.th

\section{ABSTRACT}

Aims To characterise patients with refractory SLE receiving rituximab biosimilar (CT-P10) and to explore short-term efficacy and safety associated with rituximab biosimilar use.

Methods We retrospectively analysed data from the medical records of patients with refractory SLE who received CT-P10 in Ramathibodi Hospital, Mahidol University, Thailand. Baseline characteristics, disease activity (modified Systemic Lupus Erythematosus Disease Activity Index (SLEDAI)), response to treatment at 6 months after CT-P10 and infection over 6 months were recorded. Results Thirty-two patients with SLE received CT-P10 from April 2018 to June 2019. Of these, 29 (90.6\%) were female and the mean $\pm \mathrm{SD}$ age was $36.8 \pm 15.2$ years. The median (IQR) disease duration was 9.5 (1.3-13.0) years. All patients received glucocorticoid treatment and used $1.7 \pm 0.1$ immunosuppressive agents at baseline, excluding antimalarial drugs. Baseline Systemic Lupus International Collaborating Clinics Damage Index score was 0.5 (0.01.0). Overall response, which was defined as a reduction in the modified SLEDAl score of $\geq 4$, was achieved in $25.0 \%$ of patients at 6 months. The modified SLEDAl score reduced from $4(1.3-8.0)$ at baseline to $1(0.0-5.8)$ at 6 months $(p=0.005)$. Response by active organ involvement was $71.8 \%$. Serious infection occurred in four patients $(12.5 \%)$, resulting in one death. The median time of onset of infection after CT-P10 infusion was 35.5 (17.0-72.5) days. Conclusion Rituximab biosimilar is associated with improvement in active organ involvement in patients with refractory SLE. Infection occurred early after rituximab biosimilar infusion.

\section{INTRODUCTION}

Polyclonal B cell hyper-reactivity has been well described in SLE, and B cells have been considered a potential therapeutic target. ${ }^{1}$ Rituximab (RTX) is a chimeric monoclonal antibody that depletes CD20+ B cells. Two randomised, placebo-controlled trials of RTX failed to reach their primary endpoints. ${ }^{23}$ However, other observational studies of RTX use in patients with SLE and refractory lupus are promising. ${ }^{4-11}$

Preclinical and clinical data have demonstrated the equivalence and similarity of RTX biosimilar, CT-P10, to RTX originator. ${ }^{12}$ In this retrospective cohort, our primary objective was to characterise patients with refractory lupus receiving CT-P10 and to explore its short-term efficacy and safety.

\section{PATIENTS AND METHODS}

We retrospectively analysed data of patients with refractory SLE who commenced RTX biosimilar therapy in Ramathibodi Hospital, Mahidol University, Thailand, between April 2018 and June 2019.

Patients with SLE, classified according to the 2012 Systemic Lupus International Collaborating Clinics (SLICC) criteria, aged above 16 , refractory to treatment (failure of at least one immunosuppressant), commenced a new biologic therapy with CT-P10 and with follow-up up to 6 months were included. We also included patients who expired before 6 months. Patients who previously received any biologic agent within 1 year or were diagnosed overlapping with other rheumatic diseases were excluded from the study.

Demographic data, disease duration, comorbidities and SLICC Damage Index (SDI) score were collected at baseline. Disease activity (modified SLEDAI ${ }^{13}$ ), laboratory data and immunosuppressive agents use were recorded at baseline and 6 months after the first infusion of CT-P10.

\section{Efficacy analysis}

Overall response was defined as a reduction in the modified SLEDAI-2K score of $\geq 4$. Disease flare was defined as an increase in the modified SLEDAI-2K score of $\geq 4$. Response by specific organ was defined as $\geq 50 \%$ improvement of that organ according to SLEDAI-2K Responder Index-50 (SRI-50) definitions. ${ }^{14}$ For a specific organ that was not mentioned in SRI-50, response was defined as a significant improvement $(\geq 50 \%)$ of initial disease, based on clinical judgement. Complete renal response was defined as normal kidney function (within $10 \%$ of normal GFR) and proteinuria $<0.5 \mathrm{~g} /$ day. Partial renal response was defined as near-normal GFR and $\geq 50 \%$ reduction of proteinuria to subnephrotic levels. 
Table 1 Characteristics of 32 patients with SLE receiving rituximab biosimilar

\begin{tabular}{ll}
\hline Characteristics & $\mathbf{n}(\%)$ \\
\hline Female & $29(90.62)$ \\
$\begin{array}{l}\text { Age (at first RTX biosimilar infusion), } \\
\text { mean } \pm \text { SD, years }\end{array}$ & $36.75 \pm 15.22$ \\
\hline
\end{tabular}

Disease duration, median (IQR), years $9.50(1.25-13.00)$

2012 SLICC classification criteria

Clinical criteria

\begin{tabular}{lr}
\hline Acute cutaneous lupus & $10(31.25)$ \\
\hline Chronic cutaneous lupus & $8(25.00)$ \\
\hline Oral ulcers & $5(15.62)$ \\
\hline Non-scarring alopecia & $8(25.00)$ \\
\hline Synovitis & $16(50.00)$ \\
\hline Serositis & $3(9.38)$ \\
Renal & $16(50.00)$ \\
\hline Neurological & $9(28.13)$ \\
\hline Haemolytic anaemia & $6(18.75)$ \\
\hline Leucopenia & $14(43.75)$ \\
\hline Thrombocytopaenia & $15(46.88)$ \\
\hline Immunological criteria & \\
\hline $\begin{array}{l}\text { ANA level above laboratory reference } \\
\text { range }\end{array}$ & $32(100.00)$ \\
\hline $\begin{array}{l}\text { Anti-dsDNA antibody level above } \\
\text { laboratory reference range }\end{array}$ & $18(56.25)$ \\
\hline Anti-Sm & $3(9.38)$ \\
\hline Antiphospholipid antibody positivity & $8(25.00)$ \\
\hline Low complement & $27(84.38)$ \\
\hline Direct Coombs test in the absence of & $0(0.00)$ \\
haemolytic anaemia & \\
\hline Comorbidity and damage & \\
\hline
\end{tabular}

Comorbidity and damage

\begin{tabular}{ll}
\hline Chronic HBV infection & $2(6.25)$ \\
\hline Hypertension & $8(25.00)$ \\
\hline Dyslipidaemia & $8(25.00)$ \\
\hline End-stage renal disease & $3(9.38)$ \\
\hline SLICC Damage Index, median (IQR) & $0.50(0.00-1.00)$ \\
\hline RTX biosimilar administration & \\
\hline g $\times 2$ infusions per 2 weeks & $13(40.63)$ \\
\hline 500 mg $\times 2$ infusions per 2 weeks & $10(31.25)$ \\
\hline $1 \mathrm{~g} \times 1$ infusion & $5(15.63)$ \\
\hline 500 mg $\times 1$ infusion & $1(3.13)$ \\
\hline Other regimen & $3(9.38)$ \\
\hline RTX biosimilar-associated treatment (prior/concurrent) \\
Glucocorticoids & $32(100.00)$ \\
\hline Oral & $32(100.00)$ \\
\hline Intravenous & $13(40.63)$ \\
\hline Immunosuppressive agents & $12(37.50)$ \\
\hline Intravenous cyclophosphamide
\end{tabular}

Continued

\begin{tabular}{lc} 
Table 1 Continued & $\mathbf{n}(\%)$ \\
\hline Characteristics & $2(6.25)$ \\
\hline Oral cyclophosphamide & $21(65.63)$ \\
\hline Mycophenolate mofetil & $14(43.75)$ \\
Azathioprine & $9(28.13)$ \\
Ciclosporin & $3(9.38)$ \\
Tacrolimus & $6(18.75)$ \\
Methotrexate & $23(71.88)$ \\
Hydroxychloroquine & $1.72 \pm 0.13$ \\
Number of immunosuppressive agents & \\
RTX biosimilar infusion, mean \pm SD & \\
Intravenous immunoglobulin & $4(12.50)$ \\
Plasma exchange & $4(12.50)$
\end{tabular}

dsDNA, double-stranded DNA; HBV, viral hepatitis B; RTX, rituximab; SLICC, Systemic Lupus International Collaborating Clinics.

\section{Safety analysis}

Immediate infusion reaction (within 48 hours) was recorded. Serious infections were defined as any infection requiring hospitalisation and/or intravenous antibiotics or resulting in disability or death.

\section{Statistical analysis}

Paired t-test and Wilcoxon test were used to compare paired continuous variables with normal distribution and non-normal distribution, respectively. $\mathrm{P}$ values less than 0.05 were considered statistically significant. Data were analysed using SPSS V.22.0 software.

\section{RESULTS}

\section{Patient characteristics}

A total of 32 patients were enrolled in this study. Of these, $29(90.6 \%)$ were female and the mean \pm SD age was $36.8 \pm 15.2$ years. The median (IQR) disease duration was $9.5(1.3-13.0)$ years. The median SDI and modified SLEDAI-2K scores were $0.5(0.0-1.0)$ and $4.0(1.3-8.0)$, respectively (table 1 ). The most common organ involvement during RTX biosimilar administration was lupus nephritis $(n=13)$. Six patients had more than one organ involvement.

At baseline, all patients received glucocorticoid and $1.7 \pm 0.1$ immunosuppressive agents, excluding antimalarial drugs. Mycophenolate mofetil (65.6\%), cyclophosphamide $(43.8 \%)$ and azathioprine $(43.8 \%)$ are among the most common CT-P10-associated treatment. The most common RTX biosimilar regimen was two infusions of $1000 \mathrm{mg}$ in a 2-week interval (13 patients, $40.6 \%$ ).

\section{Efficacy of RTX biosimilar}

Overall response was achieved in $25.0 \%$ of patients. The median modified SLEDAI-2K score reduced from $4(1.3-8.0)$ at baseline to $1(0.0-5.8)$ at 6 months 
Table 2 Response to rituximab biosimilar at 6 months after treatment of patients with SLE

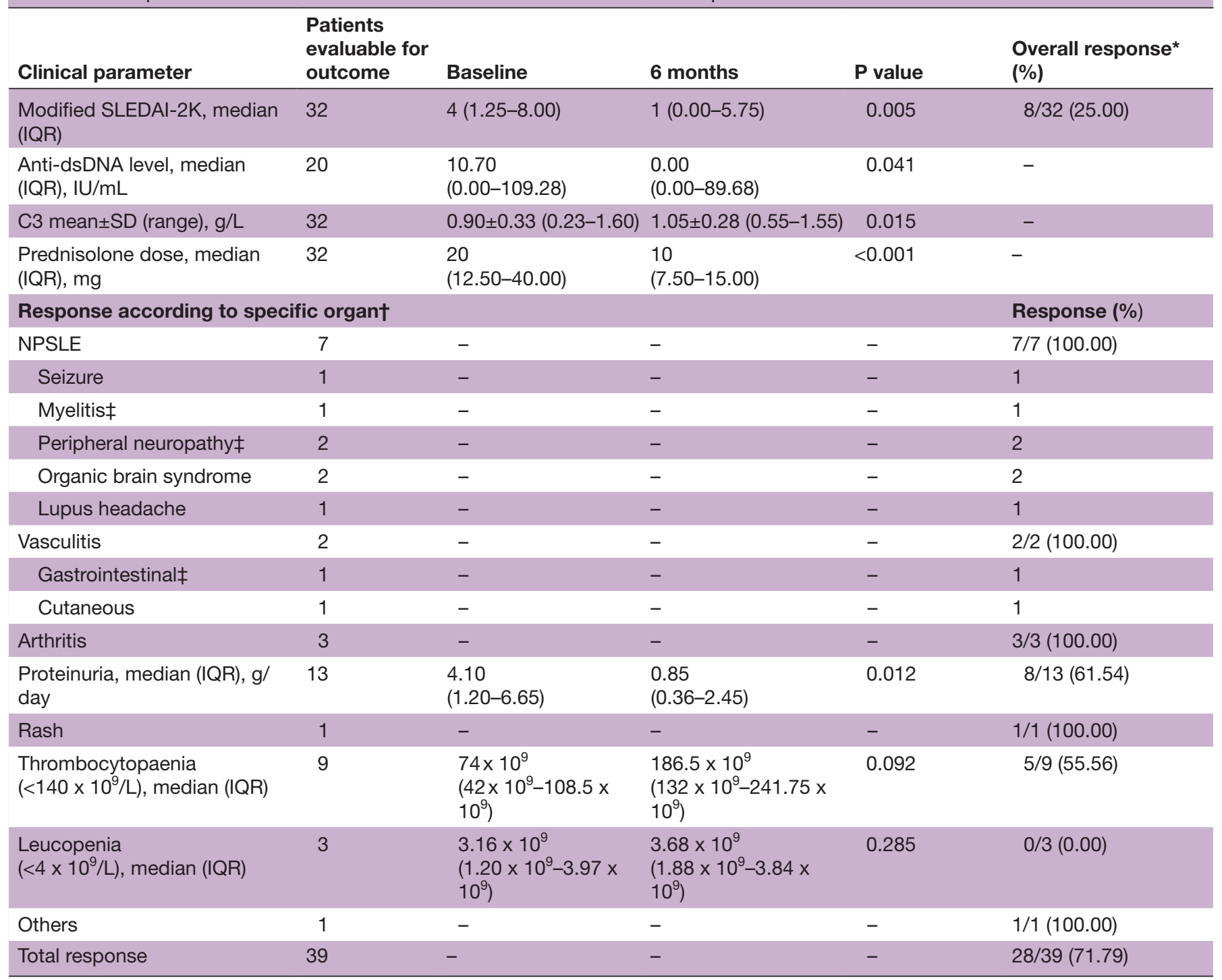

${ }^{*}$ Reduction in SLEDAI-2K or modified SLEDAI-2K score of $\geq 4$.

$\dagger \geq 50 \%$ improvement according to SLEDAI-2K Responder Index-50 definitions; six patients had more than one specific organ involvement.

$\ddagger$ Significant improvement $(\geq 50 \%)$ of initial disease, based on clinical judgement.

dsDNA, double-stranded DNA; NPSLE, neuropsychiatric SLE; SLEDAI-2K, Systemic Lupus Erythematosus Disease Activity Index-2000.

$(\mathrm{p}=0.005)$. Total response according to specific organ was $71.8 \%$ (table 2). Complete and partial renal response were achieved in three $(23.1 \%)$ and five $(15.6 \%)$ patients, respectively. Serological improvement was also observed, with an increase in C3 levels and a decrease in anti-double-stranded DNA level (table 2). RTX biosimilar treatment facilitated steroid reduction from $20(12.5-40.0) \mathrm{mg}$ to $10(7.5-15.0) \mathrm{mg}(\mathrm{p}<0.001)$. Disease flare was observed in two patients $(6.3 \%)$ at 6 months, who had new onset of microscopic haematuria and pyuria, without a decline in renal function. Details of the 32 enrolled patients are summarised in table 3.

\section{Safety of RTX biosimilar}

Immediate infusion reaction was observed in three patients $(9.4 \%)$ (flushing and skin pruritus). No severe infusion reactions were observed.
Infections were noted in six patients $(18.8 \%)$ and were severe in four patients (12.5\%). Acute pyelonephritis (3 patients, 9.4\%) and cytomegalovirus (CMV) infection (3 patients, 9.4\%) were the most common infections. Two patients had multiple infections, resulting in one death. The median time of occurrence of infections in all infected patients was 35.5 (17.0-72.5) days after CT-P10 infusion.

\section{DISCUSSION}

Our study is based on retrospective data of patients with refractory SLE using CT-P10 in actual clinical practice. Overall response was achieved in only $25.0 \%$ of patients. This number is much lower than the previous metaanalysis of RTX originator in refractory SLE that reported 
Lupus Science \& Medicine

Table 3 Characteristics, main indication for rituximab biosimilar, regimen and response to treatment of 32 enrolled patients

\section{Previous}

therapy

(other than

steroids and Specific organ

Number antimalarial) involvement

$1 \quad$ IVCY

$2 \quad$ IVCY

3 MTX, TAC MMF, IVIG

Seizure*

Transverse myelitis

Chronic inflammatory 30

demyelinating

polyneuropathy*

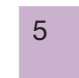

5$$
6
$$

MMF, CY

IVCY, IVIG, Acute confusional 60

PLEX

IVCY

\section{state, lupus nephritis*}

Acute confusional 75

state, lupus nephritis,
thrombocytopaenia*

state, lupus nephritis,
thrombocytopaenia*

$\begin{array}{llllllll}7 & \text { AZA, IVCY } & \text { Lupus headache* } & 20 & 1000 \times 2 & \text { AZA, CYA } & 10 & \text { Y } \\ 8 & \text { IVCY, PLEX } & \begin{array}{l}\text { Gastrointestinal } \\ \text { vasculitis*, lupus } \\ \text { nephritis (class III) }\end{array} & 50 & 1000 \times 1 & \text { MMF, IVCY } & 30 & \text { Y, Y } \\ & & & & & \end{array}$

\begin{tabular}{|c|c|c|c|c|c|c|c|}
\hline 9 & MMF, CY & Cutaneous vasculitis* & 15 & $1000 \times 2$ & MMF, AZA & 15 & Y \\
\hline 10 & CYA, IVCY & Arthritis* & 30 & $1000 \times 2$ & CYA, MTX & 10 & Y \\
\hline 11 & MTX & Arthritis* & 17.5 & $500 \times 2$ & MTX, MMF & 10 & $\mathrm{Y}$ \\
\hline 12 & MTX & Arthritis* & 5 & $500 \times 2$ & MTX, MMF & 10 & $\mathrm{Y}$ \\
\hline 13 & MMF, IVCY & Lupus nephritis* & 25 & $500 \times 2$ & MMF, TAC & 10 & Y \\
\hline 14 & IVCY, PLEX & Lupus nephritis* & 40 & $500 \times 2$ & MMF & 10 & $\mathrm{Y}$ \\
\hline 15 & $\begin{array}{l}\text { CYA, MMF, } \\
\text { IVCY }\end{array}$ & $\begin{array}{l}\text { Lupus nephritis (class } \\
\text { IV)* }\end{array}$ & 20 & $1000 \times 2$ & CYA, MMF & 10 & $\mathrm{Y}$ \\
\hline 16 & MTX, MMF & Lupus nephritis* & 1.5 & $1000 \times 2$ & MTX, MMF & 0.5 & $\mathrm{~N}$ \\
\hline 17 & CYA, MMF & $\begin{array}{l}\text { Lupus nephritis (class } \\
\mathrm{IV}+\mathrm{V})^{*}\end{array}$ & 10 & $1000 \times 2$ & CYA, MMF & 7.5 & $\mathrm{~N}$ \\
\hline 18 & MTX, MMF & Lupus nephritis* & 5 & $1000 \times 2$ & MTX, CYA, MMF & 5 & $\mathrm{~N}$ \\
\hline 19 & MMF, IVCY & $\begin{array}{l}\text { Lupus nephritis (class } \\
\text { III)* }\end{array}$ & 75 & $500 \times 2$ & MMF, IVCY & 20 & Y \\
\hline 20 & AZA, MMF & $\begin{array}{l}\text { Lupus nephritis*, } \\
\text { thrombocytopaenia }\end{array}$ & 40 & $1000 \times 1$ & AZA, MMF & 7.5 & $\mathrm{Y}, \mathrm{Y}$ \\
\hline 21 & IVCY & $\begin{array}{l}\text { Lupus nephritis*, } \\
\text { thrombocytopaenia }\end{array}$ & 60 & $500 \times 3$ & $\begin{array}{l}\text { None (expired } \\
\text { from infection) }\end{array}$ & - & $\mathrm{N}, \mathrm{N}$ \\
\hline 22 & MMF, IVIG & $\begin{array}{l}\text { Lupus nephritis } \\
\text { (class III+V)*, } \\
\text { thrombocytopaenia }\end{array}$ & 30 & $1000 \times 1$ & MMF & 20 & $\mathrm{~N}, \mathrm{Y}$ \\
\hline 23 & MMF & $\begin{array}{l}\text { Photosensitive lupus } \\
\text { rash* }\end{array}$ & 15 & $500 \times 2$ & MMF & 10 & $\mathrm{Y}$ \\
\hline 24 & $\begin{array}{l}\text { AZA, CYA, } \\
\text { MMF }\end{array}$ & Thrombocytopaenia* & 12.5 & $500 \times 2$ & AZA, CYA, MMF & 7.5 & $\mathrm{~N}$ \\
\hline 25 & MMF & Thrombocytopaenia* & 20 & $\begin{array}{l}500 \times 2 \\
1000 \times 1\end{array}$ & MMF, IVIG & 10 & $\mathrm{~N}$ \\
\hline 26 & AZA, CYA & Thrombocytopaenia* & 15 & $1000 \times 2$ & AZA, CYA & 5 & $\mathrm{Y}$ \\
\hline 27 & AZA, CYA & Thrombocytopaenia* & 15 & $1000 \times 2$ & AZA, CYA & 2.5 & $\mathrm{Y}$ \\
\hline 28 & $\begin{array}{l}\text { AZA, CYA, } \\
\text { MMF }\end{array}$ & Thrombocytopaenia* & 12.5 & $500 \times 2$ & AZA, CYA, MMF & 10 & $\mathrm{~N}$ \\
\hline 29 & AZA, TAC & Leucopenia* & 12.5 & $500 \times 2$ & AZA, TAC & 7.5 & $\mathrm{~N}$ \\
\hline 30 & $A Z A$ & Leucopenia* & 40 & $1000 \times 2$ & AZA & 25 & $\mathrm{~N}$ \\
\hline 31 & AZA, MMF & Leucopenia* & 5 & $500 \times 1$ & AZA, MMF & 5 & $\mathrm{~N}$ \\
\hline
\end{tabular}

Continued

\section{Concomitant}

therapy

Baseline RTX biosimilar (other than

prednisolone regimen $(\mathrm{mg})$ steroids and

(mg/day) $\times$ infusion(s) antimalarial)

Prednisolone at

6 months

(mg/day) involvement

$1000 \times 2$

$1000 \times 2$

$1000 \times 2$

$500 \times 2$

$1000 \times 1$

$1000 \times 1$

$A Z A$

17.5

Y, Y

Y, Y, Y

$10 \quad$ Y, Y, Y

AZA
15

Y

Y


Table 3 Continued

\begin{tabular}{llllllll}
\hline \multicolumn{2}{c}{$\begin{array}{l}\text { Previous } \\
\text { therapy } \\
\text { (other than } \\
\text { steroids and } \\
\text { antimalarial) }\end{array}$} & $\begin{array}{l}\text { Specific organ } \\
\text { involvement }\end{array}$ & $\begin{array}{l}\text { Baseline } \\
\text { prednisolone } \\
\text { (mg/day) }\end{array}$ & $\begin{array}{l}\text { RTX biosimilar } \\
\text { regimen (mg) } \\
\times \text { infusion(s) }\end{array}$ & $\begin{array}{l}\text { therapy } \\
\text { (other than } \\
\text { steroids and } \\
\text { antimalarial) }\end{array}$ & $\begin{array}{l}\text { Prednisolone at } \\
6 \text { months } \\
\text { (mg/day) }\end{array}$ & $\begin{array}{l}\text { Response } \\
\text { by organ } \\
\text { involvement }\end{array}$ \\
\hline 32 & AZA & $\begin{array}{l}\text { Coagulation factor } \\
\text { inhibitor* }\end{array}$ & 75 & $500 \times 4$ & MMF & 30 & Y
\end{tabular}

*Main indication for rituximab biosimilar infusion.

AZA, azathioprine; CY, oral cyclophosphamide; CYA, ciclosporin A; IVCY, intravenous cyclophosphamide; IVIG, intravenous immunoglobulin; LEF, leflunomide; MMF, mycophenolate mofetil; MTX, methotrexate; N, no; PLEX, plasma exchange; RTX, rituximab; TAC, tacrolimus; Y, yes.

the overall response to be $72.0 \% .{ }^{9}$ First, this discrepancy might be explained by a different definition of overall response. Second, the modified SLEDAI-2K cannot distinguish features of clinical activities that are only partly improved. Third, this index also misses out some clinical features of patients in this study. The reason for relatively low disease activity in our study may be explained by the main indication for RTX biosimilar use in 16 patients $(50.0 \%)$ being non-severe manifestations or organ that is not included in the modified SLEDAI-2K score. Response according to specific organ using more sensitive criteria able to capture partial improvement was $71.8 \%$, much higher than the overall response number.

RTX biosimilar displayed promising effects in neuropsychiatric SLE with $100 \%$ clinical response. Renal response (complete and partial) was $61.5 \%$, comparable with previous studies $(56.9 \%-67.0 \%) .{ }^{36}$ Patients with immune thrombocytopaenia demonstrated $55.6 \%$ response. Moreover, RTX biosimilar might be used as a steroid-sparing drug, demonstrated by reducing the median dose of prednisolone from $20(12.5-40)$ to $10(7.5-15) \mathrm{mg} /$ day.

Severe infections were noted in $12.5 \%$ of patients, slightly higher than a previous study of RTX originator $(4.7 \%-11.0 \%) .{ }^{57811}$ The high incidence of CMV infection in the current study $(9.4 \%)$ might be explained by the use of high-dose corticosteroids and strong immunosuppressive drug, such as intravenous cyclophosphamide. ${ }^{15}$

The majority of infections occurred in the first 2 months post RTX biosimilar infusion, when most of the patients were still in high disease activity, on high-dose steroid and a maximum period of B cell depletion. Immediate infusion reaction was $9.4 \%$, comparable with previous studies of RTX originator $(3.7 \%-21.2 \%) .{ }^{578}$

Our study possesses some limitations. First of all, the study design is retrospective. The sample size in this study is relatively small. Moreover, this study only reported short-term outcomes up to 6 months.

The unmet need in the therapeutics of SLE is to develop affordable treatment regimens that are more efficacious but associated with fewer side effects. Our findings demonstrate that RTX biosimilar achieved significant efficacy and an acceptable safety profile in refractory SLE. The results are comparable with RTX originator studies.

Contributors All authors were involved in drafting the article or revising it critically. All authors approved the final version to be published.
Funding This work was supported by the Faculty of Medicine Ramathibodi Hospital (grant number CF_63001).

Competing interests None declared.

Patient and public involvement Patients and/or the public were not involved in the design, or conduct, or reporting, or dissemination plans of this research. Patient consent for publication Not required.

Ethics approval The study was approved by the Committee on Human Rights Related to Research Involving Human Subjects (MURA2020/8), following the Declaration of Helsinki.

Provenance and peer review Not commissioned; externally peer reviewed.

Open access This is an open access article distributed in accordance with the Creative Commons Attribution Non Commercial (CC BY-NC 4.0) license, which permits others to distribute, remix, adapt, build upon this work non-commercially, and license their derivative works on different terms, provided the original work is properly cited, appropriate credit is given, any changes made indicated, and the use is non-commercial. See: http://creativecommons.org/licenses/by-nc/4.0/.

ORCID iD

Pintip Ngamjanyaporn http://orcid.org/0000-0001-7948-1748

\section{REFERENCES}

1 Liossis S-NC, Staveri C. B cell-based treatments in SLE: past experience and current directions. Curr Rheumatol Rep 2017;19:78.

2 Merrill JT, Neuwelt CM, Wallace DJ, et al. Efficacy and safety of rituximab in moderately-to-severely active systemic lupus erythematosus: the randomized, double-blind, phase II/III systemic lupus erythematosus evaluation of rituximab trial. Arthritis Rheum 2010;62:222-33.

3 Rovin BH, Furie R, Latinis K, et al. Efficacy and safety of rituximab in patients with active proliferative lupus nephritis: the lupus nephritis assessment with rituximab study. Arthritis Rheum 2012;64:1215-26.

4 Ramos-Casals M, Soto MJ, Cuadrado MJ, et al. Rituximab in systemic lupus erythematosusA systematic review of off-label use in 188 cases. Lupus 2009;18:767-76.

5 Terrier B, Amoura Z, Ravaud P, et al. Safety and efficacy of rituximab in systemic lupus erythematosus: results from 136 patients from the French autoimmunity and rituximab registry. Arthritis Rheum 2010;62:2458-66.

6 Díaz-Lagares C, Croca S, Sangle S, et al. Efficacy of rituximab in 164 patients with biopsy-proven lupus nephritis: pooled data from European cohorts. Autoimmun Rev 2012;11:357-64.

7 Witt M, Grunke M, Proft F, et al. Clinical outcomes and safety of rituximab treatment for patients with systemic lupus erythematosus (SLE) - results from a nationwide cohort in Germany (GRAID). Lupus 2013;22:1142-9.

8 laccarino L, Bartoloni E, Carli L, et al. Efficacy and safety of off-label use of rituximab in refractory lupus: data from the Italian multicentre registry. Clin Exp Rheumatol 2015;33:449-56.

9 Alshaiki F, Obaid E, Almuallim A, et al. Outcomes of rituximab therapy in refractory lupus: a meta-analysis. Eur J Rheumatol 2018;5:118-26.

10 Iwata S, Saito K, Hirata S, et al. Efficacy and safety of anti-CD20 antibody rituximab for patients with refractory systemic lupus erythematosus. Lupus 2018;27:802-11.

11 McCarthy EM, Sutton E, Nesbit S, et al. Short-Term efficacy and safety of rituximab therapy in refractory systemic lupus erythematosus: results from the British Isles lupus assessment group biologics register. Rheumatology 2018;57:470-9. 
12 Coiffier B. Pharmacokinetics, efficacy and safety of the rituximab biosimilar CT-P10. Expert Rev Clin Pharmacol 2017;10:923-33.

13 Uribe AG, Vilá LM, McGwin G, et al. The systemic lupus activity Measure-revised, the Mexican systemic lupus erythematosus disease activity index (SLEDAI), and a modified SLEDAI-2K are adequate instruments to measure disease activity in systemic lupus erythematosus. J Rheumatol 2004;31:1934-40.
14 Touma Z, Gladman DD, Ibañez D, et al. Development and initial validation of the systemic lupus erythematosus disease activity index 2000 Responder index 50. J Rheumatol 2011;38:275-84.

15 Choo HMC, Cher WQ, Kwan YH, et al. Risk factors for cytomegalovirus disease in systemic lupus erythematosus (SLE): a systematic review. Adv Rheumatol 2019;59:12. 